Article

\title{
Risk and Resilience: A Case of Perception versus Reality in Flood Management
}

\author{
Nirupama Agrawal ${ }^{1, *(\mathbb{D})}$, Mark Elliott ${ }^{2}$ and Slobodan P Simonovic ${ }^{3}$ (i) \\ 1 Disaster \& Emergency Management Program, York University, Toronto, ON M3J 1P3, Canada \\ 2 Institute for Catastrophic Loss Reduction, Toronto, ON M5C 2R9, Canada; melliott@iclr.org \\ 3 Department of Civil and Environmental Engineering, University of Western Ontario, \\ London, ON N6A 5B9, Canada; simonovic@uwo.ca \\ * Correspondence: nirupama@yorku.ca
}

Received: 28 March 2020; Accepted: 25 April 2020; Published: 28 April 2020

\begin{abstract}
Canada's vast regions are reacting to climate change in uncertain ways. Understanding of local disaster risks and knowledge of underlying causes for negative impacts of disasters are critical factors to working toward a resilient environment across the social, economic, and the built sectors. Historically, floods have caused more economical and social damage around the world than other types of natural hazards. Since the 1900s, the most frequent hazards in Canada have been floods, wildfire, drought, and extreme cold, in terms of economic damage. The recent flood events in the Canadian provinces of Ontario, New Brunswick, Quebec, Alberta, and Manitoba have raised compelling concerns. These include should communities be educated with useful knowledge on hazard risk and resilience so they would be interested in the discussion on the vital role they can play in building resilience in their communities. Increasing awareness that perceived risk can be very different from the real threat is the motivation behind this study. The main objectives of this study include identifying and quantifying the gap between people's perception of exposure and susceptibility to the risk and a lack of coping capacity and objective assessment of risk and resilience, as well as estimating an integrated measure of disaster resilience in a community. The proposed method has been applied to floods as an example, using actual data on the geomorphology of the study area, including terrain and low lying regions. It is hoped that the study will encourage a broader debate if a unified strategy for disaster resilience would be feasible and beneficial in Canada.
\end{abstract}

Keywords: disaster; risk; perception; community; resilience; Canada

\section{Introduction}

The impacts of geo-hydrologic hazards in the last two decades of the 20th century were felt by three-quarters of the population worldwide [1]. Since the 1900s, the most economically damaging disasters from natural causes in Canada were floods, wildfires, drought, and extreme cold. Recent research has linked specific flooding events, as well as a general rise in the intensity of wet weather in the northern hemisphere, to the effects of rising greenhouse gas levels and global climate change [2]. Past studies intended to focus on disaster response founded on a top-down approach, but the focus has now shifted to a community-based approach [3-9] that stresses resilience building. After the Hyogo Framework for Action (HFA), 2005-2015 [10] launched a movement for building the resilience of nations and communities to disasters. The Sendai Framework for Disaster Risk Reduction (SF-DRR) 2015-2030 [11] serves as a continuum to the commitment supported by the United Nations Office for Disaster Risk Reduction (UNDRR). The SF-DRR notes the need for improved understanding of disaster risk in all its dimensions of exposure, vulnerability, and hazard characteristics, as well as the strengthening of disaster risk governance [11]. Potential variations in the understanding of risk, 
resilience, susceptibility, and coping capacity allow for interpretations and applications in managing disasters. Scholars have analyzed and explained perceptions of risk, as a component of the social factors, which interacts with the geographic context to create vulnerability [12], as part of the cultural arrangements of society to cope with flood events [13], and as determinants of vulnerability [14,15].

The role of risk perceptions in improving the resilience of people and communities is widely recognized as an essential component [16]. While it is not possible for societies and citizens to directly influence the natural sources of hazards, much can be done to mitigate their risk by understanding and managing the consequences they could experience should a disaster occur-this is addressed by resilience [17]. The idea of disaster-resilient communities goes beyond estimating monetary losses alone but also accounting for multiple dimensions, including technical, organizational, social, and economic facets [18]. The world risk index (WRI) focuses on the understanding of risk, which is defined as the interaction of physical hazards and the vulnerability of exposed elements [19]. It also demonstrates through the assessed risk for 173 countries that the vulnerability of a society or a country is not the same as exposure to natural hazards [19].

The most comprehensive definition of resilience is developed by the UNDRR, "The ability of a system, community or society exposed to hazards to resist, absorb, accommodate, adapt to, transform and recover from the effects of a hazard in a timely and efficient manner, including through the preservation and restoration of its essential basic structures and functions through risk management." Communities or systems that can creatively reorganize themselves in the wake of disruptive events are considered resilient [20,21]. Studies have argued that community resilience is one of the main priority mechanisms for disaster risk reduction [22-27].

Coping capacity is deeply intertwined with resilience building and is a component of the broader term "capacity" that includes capacity assessment and capacity development [28]. It is the ability of people, organizations, and systems, using available skills and resources, to manage adverse conditions, risk, or disasters. The capacity to cope requires continuing awareness, resources, early warnings, and good management, both in normal times as well as during disasters or adverse conditions. Coping capacities relate to complex inter-linked factors, including coordination between institutions designed to provide support in disasters and consolidation of knowledge and methodologies to assess and deal with the identified risks at the local and national levels [11].

Disaster resilience has been the main focus in disaster-prone regions in recent times [29-36]. The latest emergency management (EM) strategy for Canada [37] also focuses on disaster resilience in the wake of intensifying natural disasters in the country [38,39] and recommends prioritizing resilience building, disaster prevention, and mitigation activities. According to this program, the concept of resilience is defined as "the capacity of a system, community or society to adapt to disturbances resulting from hazards by persevering, recuperating or changing to reach and maintain an acceptable level of functioning." The EM strategy [37] identified five priority areas and activities approved by federal/provincial/territorial (FPT) governments in Canada to strengthen overall resilience:

i. Enhance whole-of-society collaboration and governance to strengthen resilience.

ii. Improve understanding of disaster risks in all sectors of society.

iii. Increase focus on whole-of-society disaster prevention and mitigation activities.

iv. Enhance disaster response capacity and coordination and foster the development of new capabilities.

v. Strengthen recovery efforts by building back better to minimize the impacts of future disasters.

The EM strategy supports the FPT governments' vision to strengthen Canada's EM capabilities to prevent/mitigate, prepare for, respond to, and recover from disasters, to reduce disaster risk and increase the resiliency of all individuals and communities in Canada. Frequent flooding is a serious concern in Canada, as was evident from the recurring spring floods in Ontario, Quebec, and Toronto Islands during 2017-2019. Previous recent significant floods include the 2013 southern Alberta floods, the 2013 Toronto urban flood, the 2014 Saskatchewan and Manitoba floods, the 2011 Manitoba flood, 
and the 2017 British Columbia flood. A potential flooding concern for Toronto Islands is in place in 2020 as Lake Ontario levels may rise in spring.

Although the importance of community perception of risk in the decision-making process has been extensively discussed in the literature [4,8,40-44], the concept has not been applied in practice in a significant way across disciplines. Some of the reasons for that include difficulty in measuring the perception of different actors in the system, assessing the impact of the inclusion of opinion in risk assessment and disaster risk reduction (DRR) policy, and, most of all, designing and collecting relevant data. Perceived resilience is key to comprehend and estimate as it relates to how people perceive risk (exposure to hazards), vulnerability (susceptibility), and their capacity to cope including the institutional support. In survey-based qualitative research, it has been established that post-disaster experiences of affected communities show their preference for coping actions align with their individual personalities [3,45-48]. It is clear that pre-disaster preparedness and capacity building very much depends on how people "feel" about the probability of another disaster to occur in their community $[3,49]$. A recent study has used a questionnaire survey to evaluate risk perception for risk awareness and to increase resilience in schools [50]. It is worth noting here that people's participation in community-based disaster management must not merely be an illusion of inclusion [51,52].

There is considerable interest in disaster resilience as a mechanism for mitigating the impacts on local communities, yet the identification of metrics and standards for measuring resilience remains a challenge [53]. By measuring baseline characteristics of communities, changes in disaster resilience over time can be monitored by estimating the individual drivers of the disaster resilience (or lack thereof)-social, economic, institutional, infrastructure, and community capacities [53]. Conventionally, quantitative methods for disaster risk assessment are better understood and also preferred as they tend to be based on numbers and indices [19,54-57]. However, interactions between the makeup of the communities, their priorities, and general vulnerabilities, and the geomorphology of the region are natural and must be integrated holistically in risk and resilience assessment [12,58-64]. On the other hand, qualitative methods are generally based on surveys, focus groups, questionnaires, and interviews. The data collected from these methods is then examined, thematized, and analyzed for the understanding and interpretation of a variety of phenomena [65-67]. Qualitative techniques are useful for measuring the impact of policy, needs-assessment of communities, and understanding of people's behaviour and preferences during and post-disaster $[68,69]$. While the most common approach in research is to apply one of the two methods, quantitative or qualitative, this study integrates both techniques with the intent to capture people's perception as well as the reality on the ground. Therefore, the focus of this study is to explore how to evaluate and incorporate people's perceptions of risk, exposure, susceptibility, and coping capacity to realize gaps between perceived disaster resilience and objectively assessed disaster resilience. Once these gaps are identified, mitigation measures, coping capacity building efforts, and adaptivity initiatives can be developed and implemented with greater success. Based on these principles, a national strategy must be considered and prepared for a more comprehensive application for disaster risk management. The following sections outline the data used in the study, the methodology developed and used on a Canadian city, discussion of the results, and concluding remarks.

\section{Materials and Methods}

The method proposed in this study is an adapted and extended version of the world risk index (WRI) method [19]. While the WRI measures disaster resilience only objectively, the technique proposed here evaluates people's perception of disaster resilience (function of exposure, susceptibility, and coping capacity) and incorporates their opinion into the assessment of perceived resilience. Previous studies have shown that a questionnaire survey is a useful tool to capture risk awareness and perception of the population to help plan future risk management efforts and encourage a resilience culture in the community [47,50]. In this study, objective and perceived resilience are being evaluated and compared, gaps between perceived and actual resilience are identified, and an integrated resilience is calculated, 
as well. Community participation is essential in effective and successful disaster management in communities, and this point has been validated by various studies that are based on simulation-based planning tools, basically to engage stakeholders in a user-friendly manner $[55,70]$.

Perceived measurements-In order to incorporate people's perceptions, we have used questionnaire surveys to collect data from four different locations in the City of Brampton in the Greater Toronto Area (GTA) of Canada (Figure 1). The selection of the survey sites was made based on a good representation of the community. Specifically, a sports and community centre (survey location 1) that also houses the public library and a swimming pool, a multicultural community centre (survey location 2), a church (survey location 3), and a restaurant (survey location 4), are places regularly used by the community. We received 100 responses to the questionnaire consisting of 29 questions designed to reflect people's perceptions of threats from natural hazards, how they would cope in emergencies, their background, and how they engage in their local environment. We explained the nature and intent of the study to each participant, including what is meant by risk, how it is a function of different elements, including exposure to hazards. However, it should be noted that at the time of the survey, the exact buffer zones to estimate exposure had not been determined and, therefore, were not communicated to the survey participants. The precise nature of the questions and how they relate to model parameters is given later in this section. People's perceptions are treated as representative of the entire city for demonstrating the methodology leading to the perceived assessment of community resilience (Table 1).

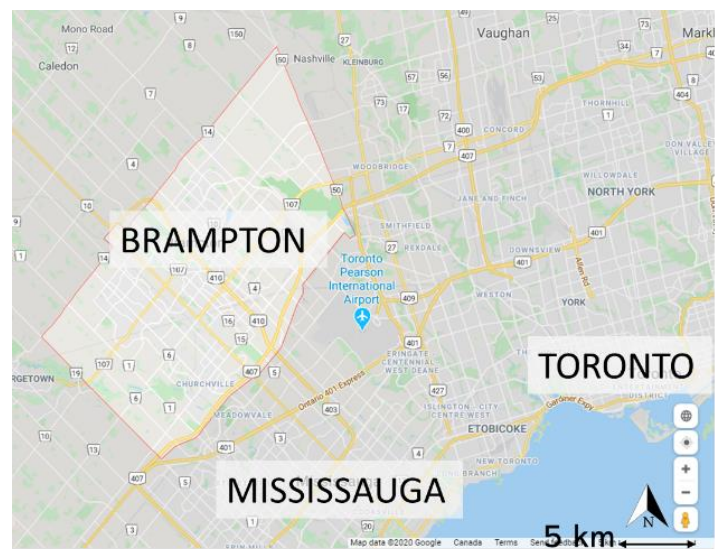

(a)

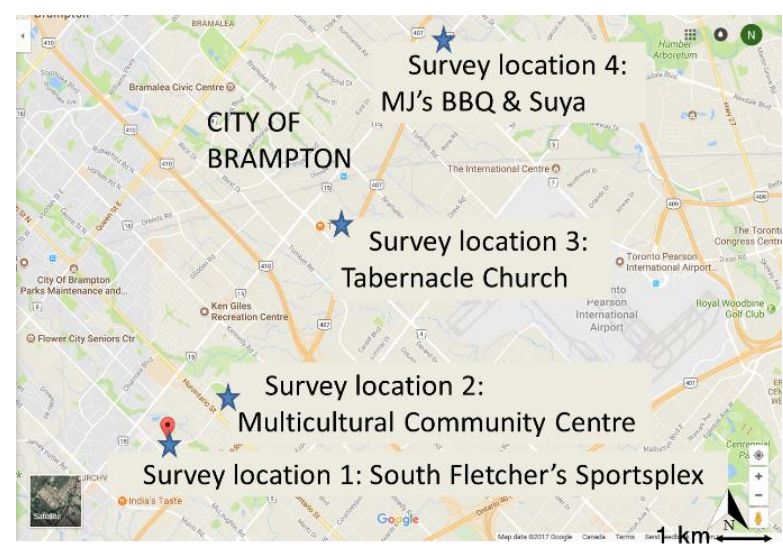

(b)

Figure 1. (a) Part of the Greater Toronto Area (GTA) for perspective purposes showing the City of Mississauga and the City of Toronto in the south and southeast of Brampton; (b) the four survey locations in Brampton: survey location 1: South Fletcher's Sportsplex community centre, survey location 2: Brampton multicultural community centre; survey location 3: New Birth Tabernacle, a non-denominational faith gathering center; and survey location 4: a local restaurant.

We have used the Thiessen polygons method to aggregate the surveyed areas for the entire city by dissemination areas (DAs) - areas of equal density of population, for perceived assessment of the parameters used in the methodology (Figure 2). The Thiessen polygon technique appropriately assigns areal significance to each survey site by constructing perpendicular bisectors to the lines joining each site with those immediately surrounding it. These bisectors form a series of polygons, each polygon containing one site. The data collected at a site gets assigned to the whole area covered by the enclosing polygon. 


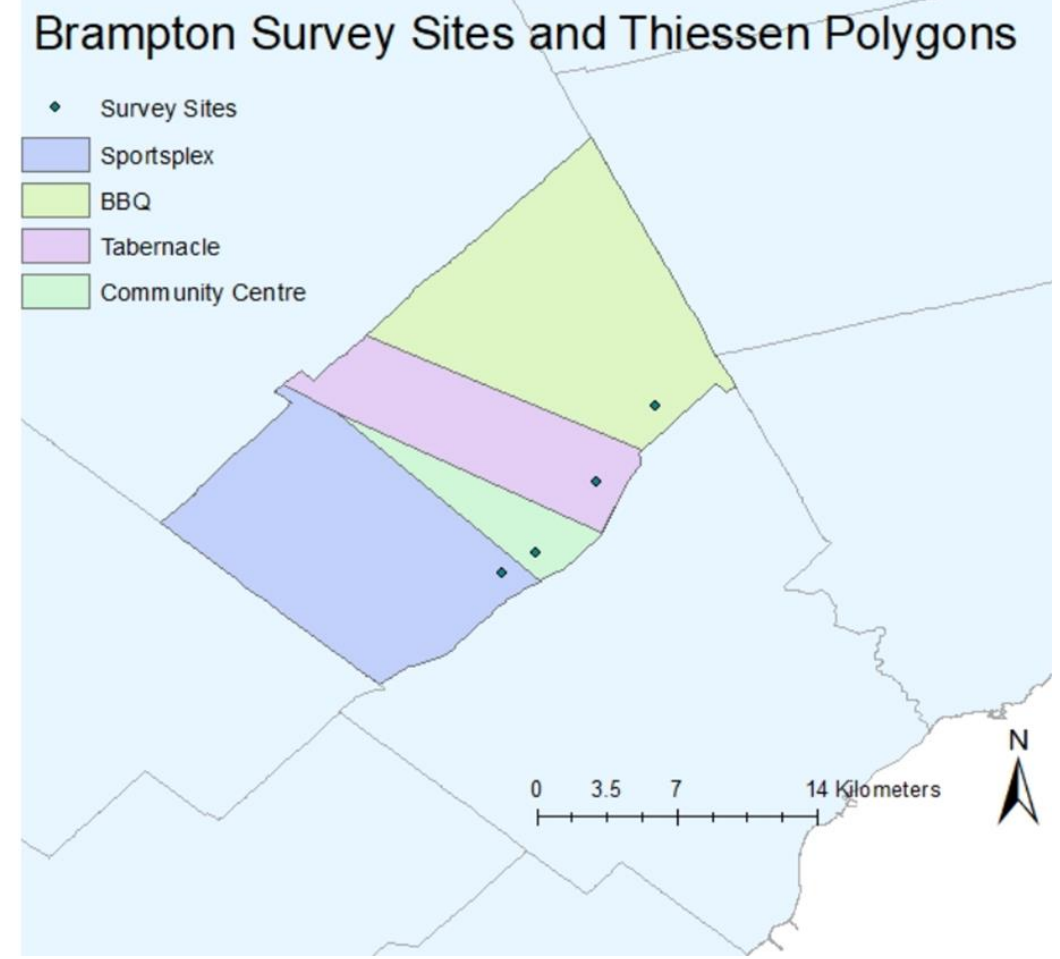

Figure 2. The City of Brampton survey sites and Thiessen polygons (TP) for perceived parameters' assessment. The TP technique appropriately assigns areal significance to each survey site.

It is worth noting here that two survey locations, BBQ and Tabernacle church, shown in Figure 1b, were lumped together as one entity, "BBQ and Tabernacle" for calculations in GIS. The reason being, the total number of responses collected from the two locations combined was rather small (14) compared to the other sites.

As demonstrated in Table 1, three parameters, namely exposure, susceptibility, and lack of coping capacity, are appropriately extracted from the responses to the survey questions by assigning binary values to them. Each parameter is comprised of several variables, representative of the parameter [19,71-73]. Although we have presented a select set of variables to represent each of the three parameters to demonstrate the method, these should not be taken as exhaustive. Disaster types, geomorphology, landuse of the region, and demographics of the population must be taken into account in the determination of these variables. The three parameters are allocated weights according to their assumed influence in this particular case study [55]. The weights can vary depending on the impact of each parameter on community resilience. For example, a known dangerous environment (high exposure), a prosperous and educated neighbourhood (low susceptibility), and an accessible network of emergency services (high coping capacity) must guide how the parameters can be weighted. For example, the residential development in the Barker reservoir in Houston, Texas, that got flooded during Hurricane Harvey [74], will have a high exposure. Table 1 summarizes the proposed process, including a guide to assigning binary values to individual variables as part of the methodology developed to account for people's input in the process of resilience assessment. For example, the parameter exposure is based on dangerous locations such as:

- $\quad$ River (flood risk)

- The transportation network (risk from derailment, explosion, oil spill)

- Chemical plants and hazardous industries

- Transmission lines (elevated health risk from high voltage corridors) 
- Oil and gas pipelines (toxic spills)

- Garbage dumpsites (a potential failing of large piles, health, and environmental hazard)

The parameter, susceptibility, comprises the following seven variables:

- Ownership/renting status of the residence

- Crowdedness factor based on the number of members in the household

- Language ability-English or French

- Employment status

- Job satisfaction

- Age-assuming that the very young and the very old would be more susceptible to the exposure to the disaster risk

- Persons with disability

Similarly, the parameter, lack of coping capacity comprises the following variables:

- Level of education

- Family income

- Means of transportation (personal or public)

- Social network support

- Disaster experience by family or friends

- Importance of disaster preparedness

- Engagement in local politics as a proxy of participation

Objective measurements-We have used the 2011 census of Canada for demographic information, Municipal Property Assessment Corporation (MPAC) average property values, slopes and terrain of the region, and landuse. The landuse data is valuable for determining the location of critical infrastructure and critical facilities for the assessment of objective parameters. The GIS software, ArcGIS, is used for data processing and analysis according to the dissemination area (DA) map of the study area. Appendix A lists all the data sources. Figure 3 shows the municipal boundaries and dissemination areas in the GTA. Figure 4 presents datasets, cropped for the City of Brampton, used for parameters estimation proposed in this method. 
Table 1. Information extracted from the four surveys toward perceived resilience along with assigned weights and binary values, where the total of all assigned weights $\sum W_{i}=1$.

\begin{tabular}{|c|c|c|c|c|}
\hline Parameter & \multicolumn{4}{|c|}{ Guidance for Assigning Binary Values 0 or 1 Based on Response to the Survey } \\
\hline \multirow[b]{2}{*}{ Exposure Weight $W_{1}$} & Question & Binary value $=0$ & Binary value $=1$ & Remarks \\
\hline & $\begin{array}{l}\text { I live near a hazardous situation } \\
\text { such as a river, chemical plant, etc. }\end{array}$ & If false & If true & $\begin{array}{l}\text { Add all binary numbers to get } \\
\text { total exposure }\end{array}$ \\
\hline \multirow{8}{*}{ Susceptibility Weight $W_{2}$} & Question/variable & $\begin{array}{c}\text { Binary value }=0 \text { if response is } \\
\text { as below }\end{array}$ & $\begin{array}{c}\text { Binary value }=1 \text { if response is } \\
\text { as below }\end{array}$ & Remarks \\
\hline & My home is & Owned & Rented or other & \multirow{7}{*}{$\begin{array}{l}\text { Add all binary numbers to ge } \\
\text { total susceptibility }\end{array}$} \\
\hline & $\begin{array}{l}\text { \# members in household } \\
\text { (crowdedness) }\end{array}$ & $<4$ & $>4$ & \\
\hline & Language (English) & very well/good & moderate/poor/blank & \\
\hline & Employment & Full time/self-employed & Part time/retired & \\
\hline & Job satisfaction & Very satisfied/satisfied & $\begin{array}{c}\text { Somewhat satisfied/not } \\
\text { satisfied/blank }\end{array}$ & \\
\hline & Age & $>20$ and $<65$ & $<20$ and $>65$ & \\
\hline & Disability & No & Yes & \\
\hline \multirow{8}{*}{ Lack of Coping Capacity Weight $W_{3}$} & Question/variable & $\begin{array}{c}\text { Binary value }=0 \text { if response is } \\
\text { as below }\end{array}$ & $\begin{array}{c}\text { Binary value }=1 \text { if response is } \\
\text { as below }\end{array}$ & Remarks \\
\hline & Education & College and higher & Less than college & \multirow{7}{*}{$\begin{array}{l}\text { Add all binary values to get } \\
\text { total lack of coping capacity }\end{array}$} \\
\hline & Income & $>50 \mathrm{~K}$ & $<50 \mathrm{~K}$ & \\
\hline & Transportation & Personal vehicle & Public/rideshare & \\
\hline & Social network & Very important & Important/somewhat/other & \\
\hline & Disaster experience & Yes & No/blank & \\
\hline & Disaster preparedness option & Family/friend & Public shelter/blank & \\
\hline & Voted in the past election & Yes & No/blank/n/a & \\
\hline
\end{tabular}




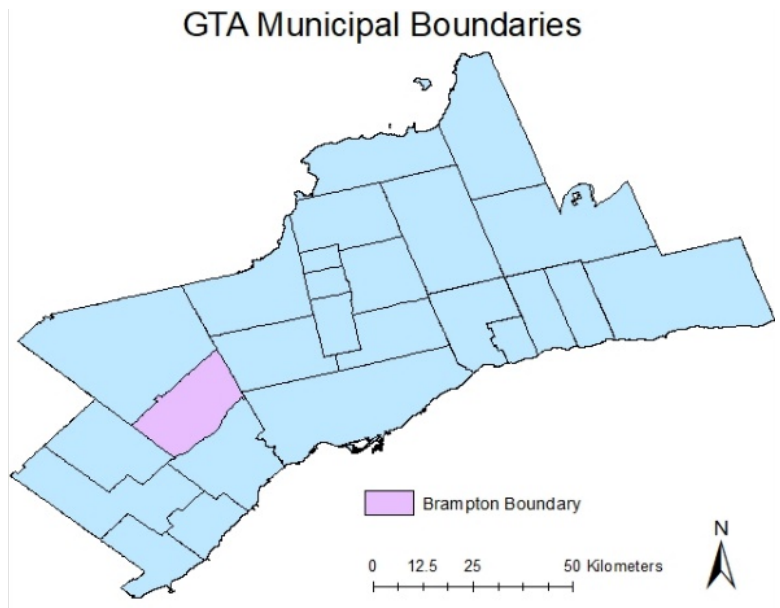

(a)

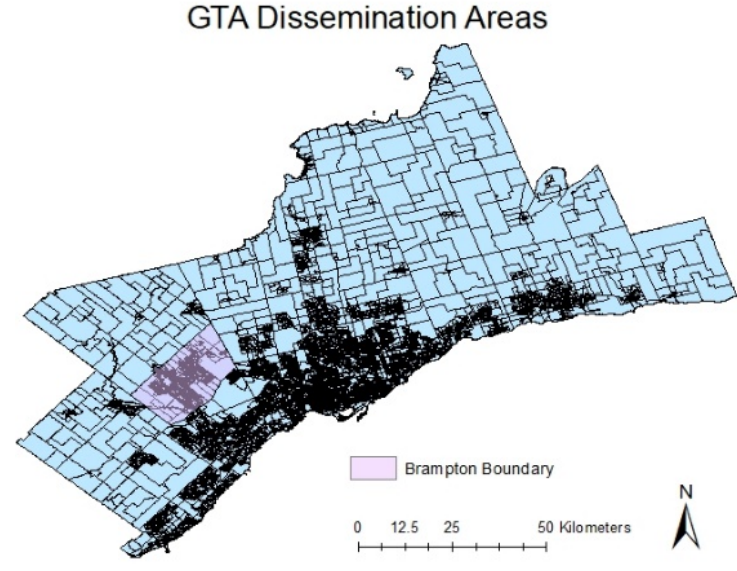

(b)

Figure 3. (a) GTA municipal boundaries, and (b) dissemination areas. City of Brampton is shown in purple.

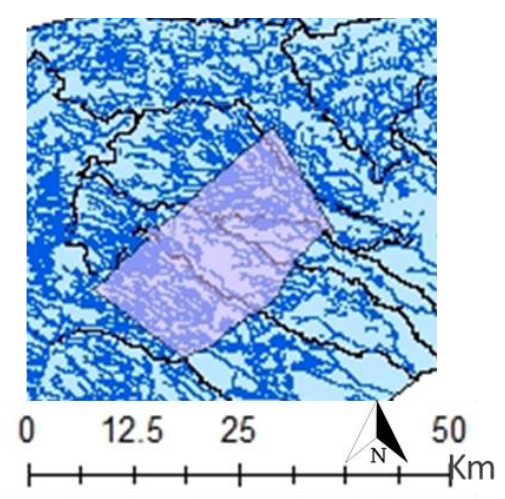

(a)

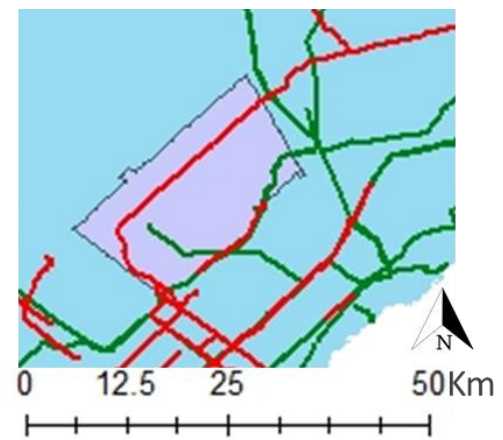

(d)

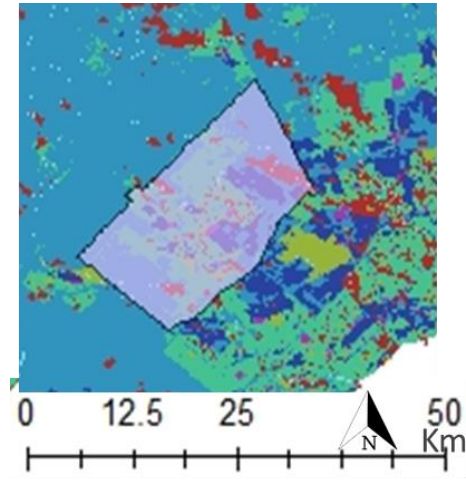

(b)

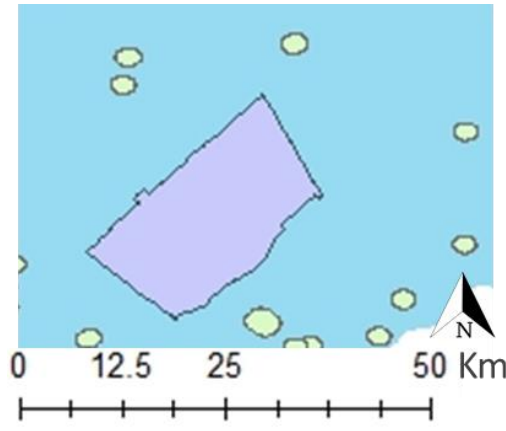

(e)

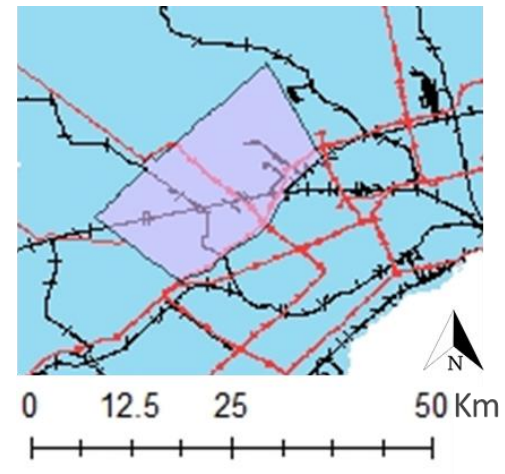

(c)

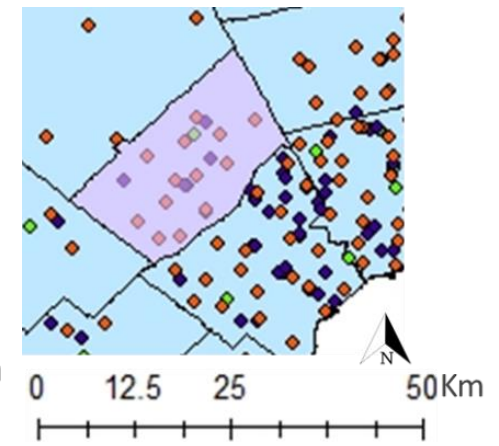

(f)

Figure 4. Objective datasets for the City of Brampton (purple boundary): (a) watercourses, (b) landuse, (c) pipelines in red and transmission lines in green, (d) the highways in red and the railways in black, (e) dumpsites in yellow circles, and (f) emergency services.

The landuse data in Figure $4 \mathrm{~b}$ includes residential (green), commercial (dark purple), government and institutional infrastructure (green), industrial (dark blue), parks and recreational (red), and open area (blue). Similarly, in Figure 4f, emergency services include fire stations (red), police stations (dark blue), and hospitals in green. It should be noted that none of the dumpsite buffers fall within the boundary of the city and, therefore, do not contribute toward exposure in this case study.

Table 2 summarizes the process of quantifying individual variables within each of the three parameters as part of the methodology. Real datasets explained and illustrated in Figure 4 earlier have been used in the measurement of the model parameters: exposure, susceptibility, and lack of coping 
capacity. Some of the processed data are shown in Figure 5. For example, exposure is determined based on whether or not a resident is located in proximity of (within a kilometer of) a highway, railway, river, industrial site, pipeline, transmission line, oil and gas facility, or dumpsite. Similarly, objective assessment of susceptibility is derived from census data, including the residence type, the age of its construction, the property value, language skill, employment status, and disability rate. The lack of coping capacity is derived from census and GIS data; it includes, income, education, a distance of more than one kilometer from emergency services, a fire station, police service, or ambulance service. See Figure 5 for the visuals of the buffer zones.

Table 2. List of parameters and variables for the objective assessment of community resilience. The total of all assigned weights $\sum W_{i}=1$.

\begin{tabular}{|c|c|c|c|c|}
\hline Parameter & & teria to Assign Bina & Values to Variables & \\
\hline \multirow[b]{2}{*}{$\begin{array}{l}\text { Exposure Weight } \\
\qquad W_{1}\end{array}$} & Variable & Binary value $=0$ & Binary value $=0$ & Remarks \\
\hline & $\begin{array}{l}\text { Highways, Railway } \\
\text { tracks, River and } \\
\text { creeks, Industries, Oil } \\
\text { and gas pipelines, } \\
\text { Dumpsites-stockpiles, } \\
\text { Low lying areas } \\
\text { (terrain/slope) }\end{array}$ & $\begin{array}{l}\text { If no exposure to a } \\
\text { potential hazard }\end{array}$ & $\begin{array}{l}\text { If within } 1 \mathrm{~km} \\
\text { buffer zone of any } \\
\text { of the potentially } \\
\text { hazardous } \\
\text { situations }\end{array}$ & $\begin{array}{l}\text { Add all binary } \\
\text { assigned values to } \\
\text { get total exposure }\end{array}$ \\
\hline \multirow{8}{*}{$\begin{array}{l}\text { Susceptibility } \\
\text { Weight } W_{2}\end{array}$} & Variable & Binary value $=0$ & Binary value $=1$ & Remarks \\
\hline & Residence type & Detached/semi & Rented apartment & \multirow{7}{*}{$\begin{array}{l}\text { Add all binary } \\
\text { assigned values to } \\
\text { get total } \\
\text { susceptibility }\end{array}$} \\
\hline & $\begin{array}{l}\text { Age of property } \\
\text { construction }\end{array}$ & Post-1980 & Pre 1980 & \\
\hline & Language & very well/good & moderate/poor/blank & \\
\hline & Employment & $\begin{array}{c}\text { Full } \\
\text { time/self-employed }\end{array}$ & Part time/retired & \\
\hline & Age & $>20$ and $<65$ & $<20$ and $>65$ & \\
\hline & Disability & No & Yes & \\
\hline & Property value & $>400 \mathrm{~K}$ & $\leq 400 \mathrm{~K}$ & \\
\hline \multirow{7}{*}{$\begin{array}{c}\text { Lack of Coping } \\
\text { Capacity Weight } \\
W_{3}\end{array}$} & Variable & Assign value $=0$ & Assign value $=1$ & Remarks \\
\hline & Education & College and higher & Less than college & \multirow{6}{*}{$\begin{array}{l}\text { Add all binary } \\
\text { assigned values to } \\
\text { get total lack of } \\
\text { coping capacity }\end{array}$} \\
\hline & Income & $>50 \mathrm{~K}$ & $\leq 50 \mathrm{~K}$ & \\
\hline & $\begin{array}{c}\text { Disaster preparedness: } \\
\text { Hospital }\end{array}$ & $\leq 1 \mathrm{~km}$ & $>1 \mathrm{~km}$ away & \\
\hline & $\begin{array}{l}\text { Disaster preparedness: } \\
\text { ambulance service }\end{array}$ & $\leq 1 \mathrm{~km}$ & $>1 \mathrm{~km}$ away & \\
\hline & $\begin{array}{l}\text { Disaster preparedness: } \\
\text { Health emergency } \\
\text { services }\end{array}$ & $\leq 1 \mathrm{~km}$ & $>1 \mathrm{~km}$ away & \\
\hline & $\begin{array}{l}\text { Disaster preparedness: } \\
\text { Police station }\end{array}$ & $\leq 1 \mathrm{~km}$ & $>1 \mathrm{~km}$ away & \\
\hline
\end{tabular}




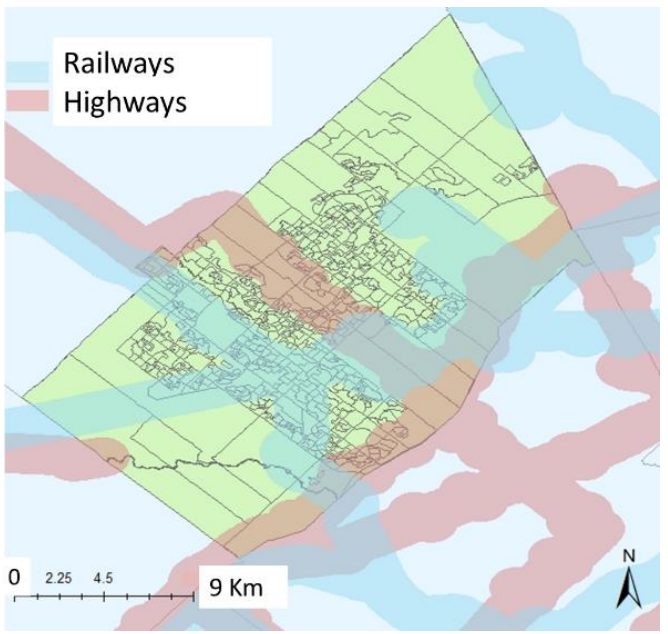

(a)

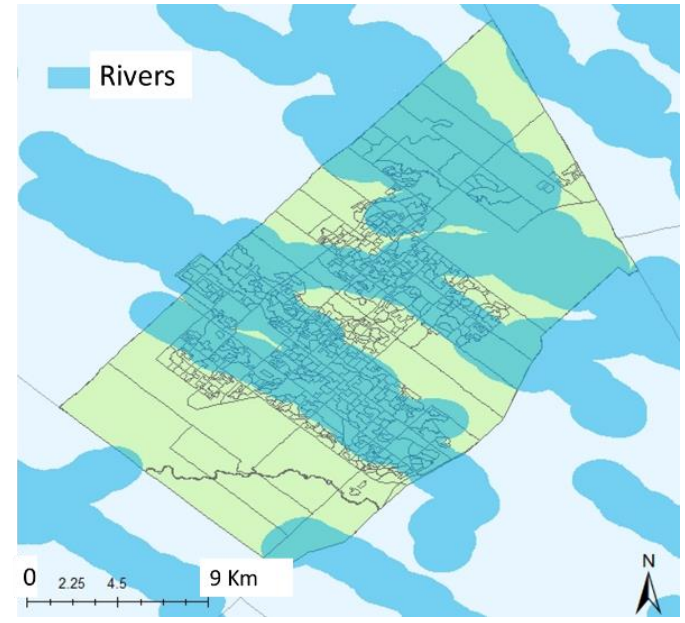

(c)

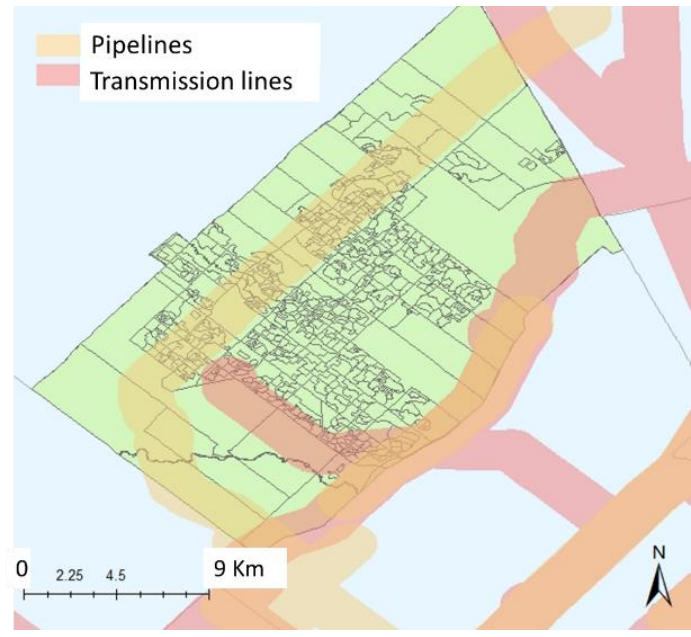

(b)

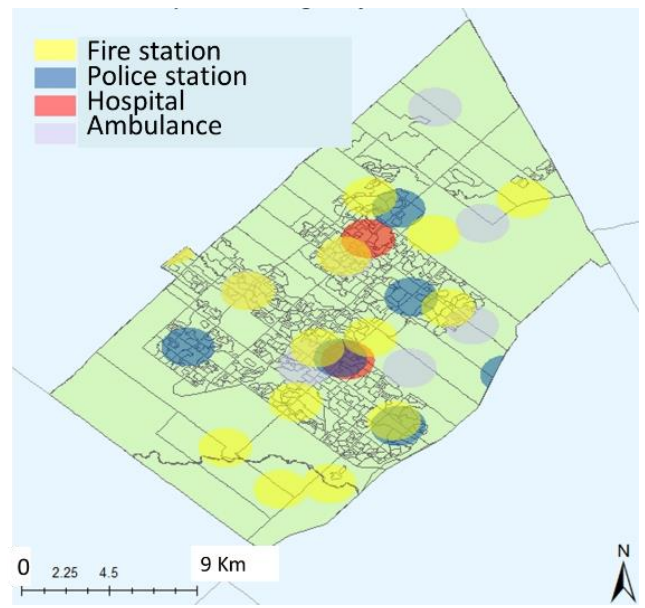

(d)

Figure 5. The City of Brampton: dissemination areas superimposed (a) with buffer zones of $1 \mathrm{~km}$ around the transportation network, railways in blue and highways in pink; (b) transmission lines in pink and gas pipelines in blue; (c) rivers in blue to demarcate exposure zones; and (d) buffer zones of $1 \mathrm{~km}$ around emergency services to assess lack of coping capacity including fire stations in yellow, police stations in blue, hospitals in red, and ambulance services in a light purple.

The overall resilience is calculated using Equations (1) to (6), derived from the WRI method [19]. Precisely, Equation (1) calculates the Lack of Resilience using objective data for the three parameters that are individually normalized. The parameters can be weighted using weights thought to be appropriate for this case study for demonstration purposes. The weights $\left(W_{1}, W_{2}, W_{3}\right)$ are open to adjustment in individual cases depending on the potential influence of the parameters, as well as the objective of the study. For example, a vulnerable community is perceived as more susceptible in comparison to an affluent neighbourhood. Residential development well outside of flood zones indicates a lower level of exposure even though the population may be regarded as vulnerable. If the community is at a substantial distance from a healthcare facility, it may reflect a lack of coping capacity in emergencies. Therefore, in this scenario, it will make sense to allocate a lower percentage of weight to "Exposure" and higher percentage to "Lack of Coping Capacity" and "Susceptibility." For the application and demonstration of the methodology, we have assigned weights to the parameters as given in Equation (2) for both objective and perceived calculations.

Equation (3) gives the estimate of Resilience using objective data, Equation (4) estimates Resilience using perceived data, and Equation (5) determines the combined Resilience by summing up the 
perceived and objective Resilience estimates. We propose here that the combined Resilience is a way to account for perceived and real measures of community resilience.

$$
\begin{aligned}
& \text { Lack of Resilience } \text { Objective } \\
& =W_{1} \times \text { Exposure }_{\text {Objective }}+W_{2} \times \text { Susceptibility }_{\text {Objective }} \\
& +W_{3} \times \text { Lack of Coping Capacity }_{\text {Objective' }}
\end{aligned}
$$

where $\sum W_{i}=1$

Lack of Resilience Objective

$$
\begin{gathered}
=0.2 \times \text { Exposure }_{\text {Objective }}+0.4 \times \text { Susceptibility }_{\text {Objective }} \\
+0.4 \times \text { Lack of Coping Capacity } \\
\text { Objective } \\
\text { Resilience }_{\text {Objective }}=1-(\text { Lack of Resilience })_{\text {Objective }} \\
\text { Resilience }_{\text {Perceived }}=1-(\text { Lack of Resilience })_{\text {Perceived }} \\
\text { Resilience }_{\text {combined }}=\text { Resilience }_{\text {Perceived }}+\text { Resilience }_{\text {Objective }}
\end{gathered}
$$

The estimated total resilience has been calculated by normalizing the combined resilience estimates using Equation (6):

$$
\text { Resilience }=\frac{\text { Resilience }_{\text {combined }_{\text {d }}}-\text { MIN }\left(\text { Resilience }_{\text {combined }}\right)}{\left(\text { MAX }\left(\text { Resilience }_{\text {combined }}\right)-\text { MIN }\left(\text { Resilience }_{\text {combined }}\right)\right)}
$$

It is noteworthy that Equations (3) and (4) were calculated using normalized and unweighted individual parameters in Equation (2), leading to an adjusted maximum total value of perceived (and objective) Resilience. The objective and perceived resilience calculations are done using the same formula.

\section{Results}

The findings of the research are illustrated through Figures 6-8. Objective and perceived measures were made for the survey sites. The actual datasets on the geomorphology of the study area, including rivers and low lying regions, indicate that the method has been applied to a flooding scenario as an example. As mentioned earlier, two survey locations, namely, BBQ and Tabernacle church, were lumped together as one entity, "BBQ and Tabernacle" for calculations in GIS due to the small number of responses from the two locations. Each of the three parameters was calculated separately to achieve perceived and objective estimates of them for each survey location. Figure 6 shows objective measures of the three model parameters, namely, Exposure, Susceptibility, and the Lack of Coping Capacity calculated for survey location 2, the Community Centre. Similar maps were obtained for perceived measures of the three parameters. Also, similar maps were developed for other survey locations. In total, 12 maps were obtained for objective and perceived estimates of the three parameters for the three survey locations. Although it may be desirable for the readers to visualize the step-by-step development of these maps, to avoid overcrowding of illustrations, selected graphs are presented here. 


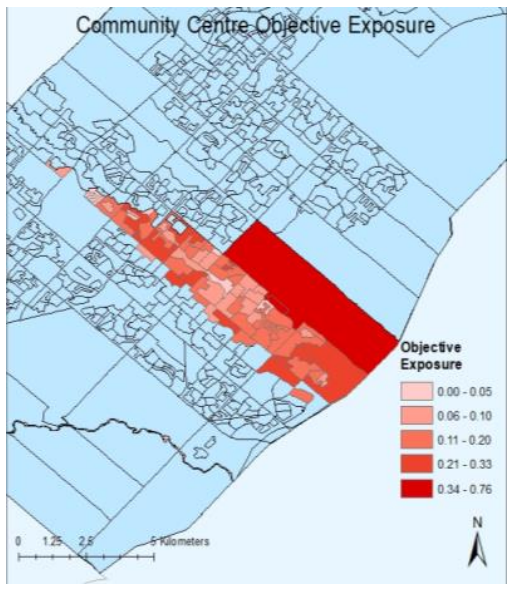

(a)

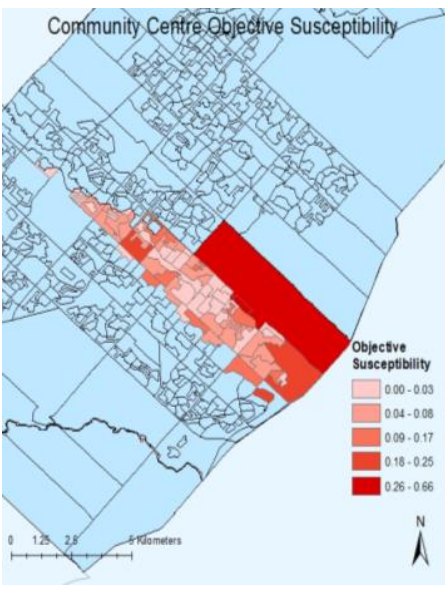

(b)

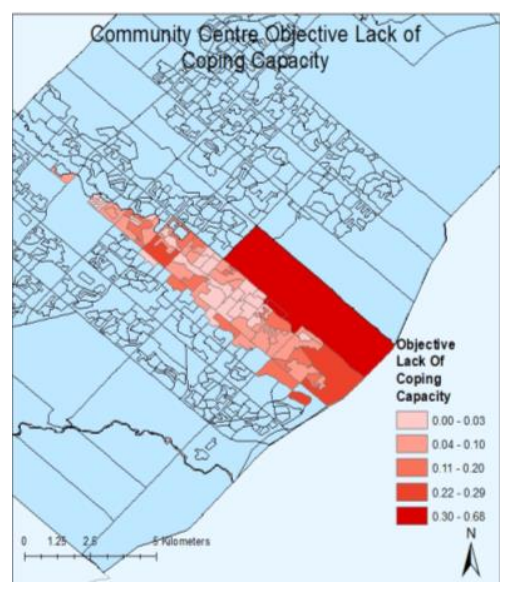

(c)

Figure 6. Objective measures of the three parameters for one of the three survey areas: (a) exposure, (b) susceptibility, and (c) lack of coping capacity. Similar maps were obtained for the other two survey areas but are not shown here.

Figure 7 shows the integrated (perceived plus objective) measure of Resilience for the three survey locations, separately. Figure 8 is a picture of the perceived and objective Resilience measures for the entire City of Brampton, and Figure 9 represents the integrated resilience map for the city. Each of the three parameters was normalized before being weighted in Equation (1). Therefore, as can be seen in Figure 8, the two resilience maps show estimates of up to 63 for perceived Resilience and up to 89 for the objective Resilience. It is noteworthy that the method suggests the ideal resilience value to be 100. Therefore, objective resilience gives a better level of resilience in the study area as compared to perceived measure of resilience. In essence, the maximum value of objective resilience is higher than perceived resilience, and the higher the value of resilience, the better in each case scenario.

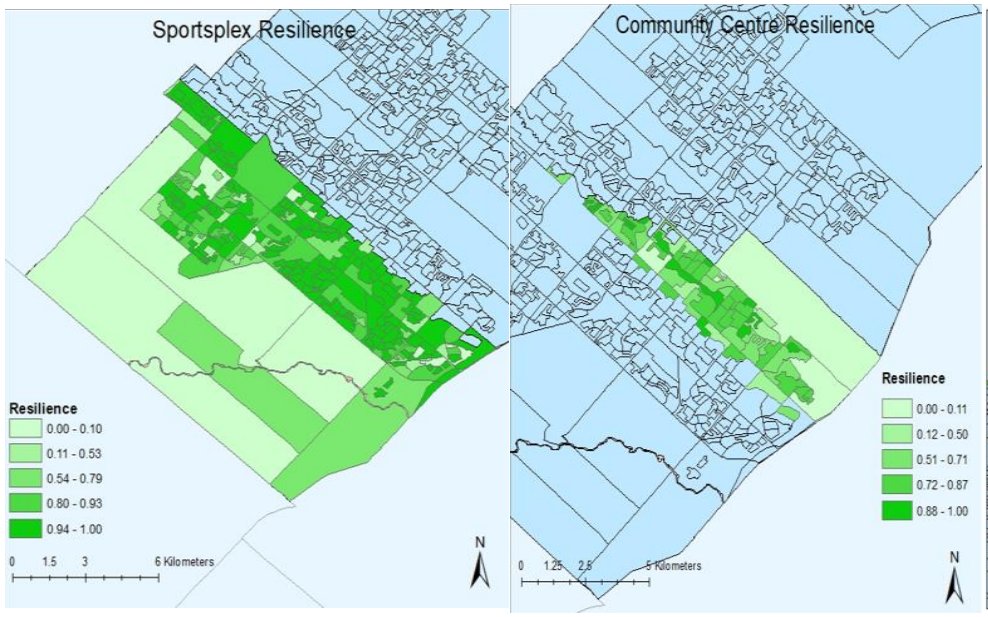

(a)

(b)

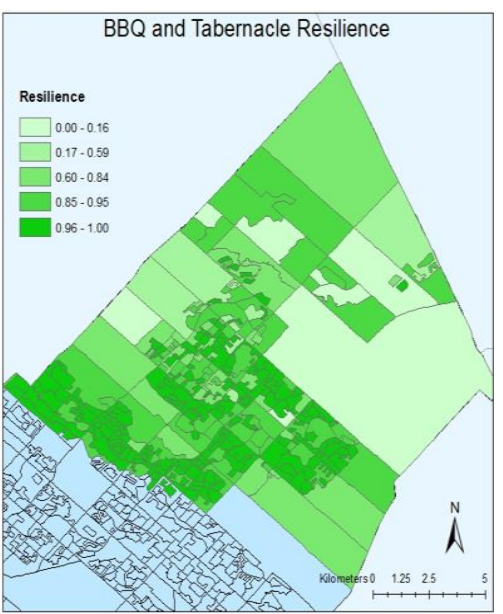

(c)

Figure 7. The measure of total resilience (perceived plus objective) for the three survey sites: (a) Location 1, (b), Location 2, and (c) Location 3. 


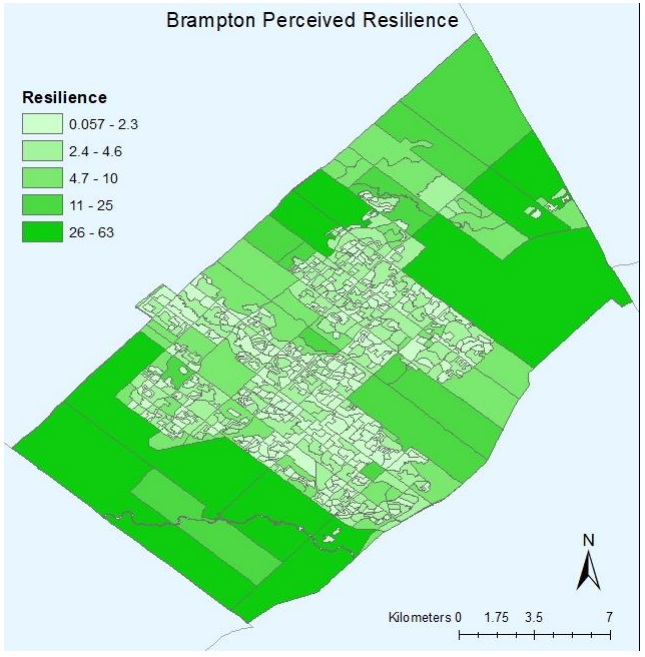

(a)

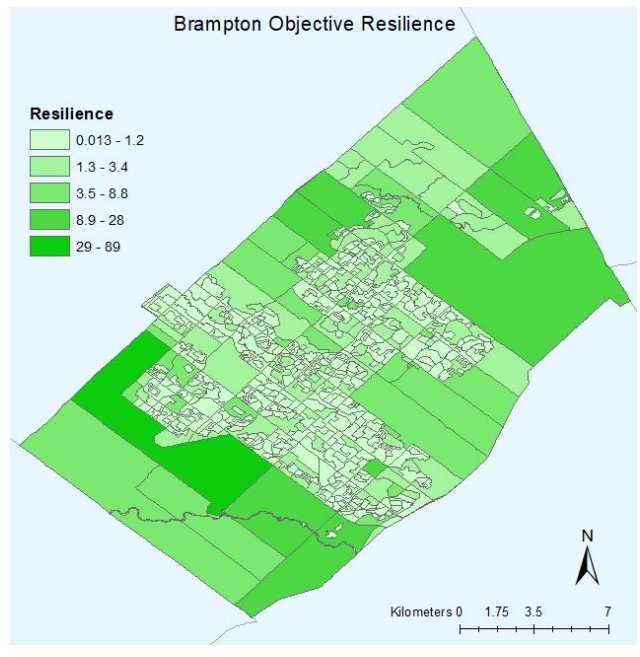

(b)

Figure 8. Resilience maps aggregated for the City of Brampton (in percentage): (a) perceived, and (b) objective.

Although Figure 8 is the key outcome of this study, Figure 9 has been arrived at by combining the two resilience measures, showing the regions of variable resilience. It is useful to see how the two measures of resilience may have aligned with each other, positively or negatively. In future research, it would be helpful to subtract the two resilience measures from each other and visualize where the gaps are between the public perception and the reality on the ground. The shades of green indicate levels of resilience of the community, the darker, the better. The shades of yellow and parts of red are in regions where rivers and creeks flow. The areas shown in red indicate low resilience due to a variety of reasons such as industrial areas, flood zones, low lying areas, and a dense network of watercourses.

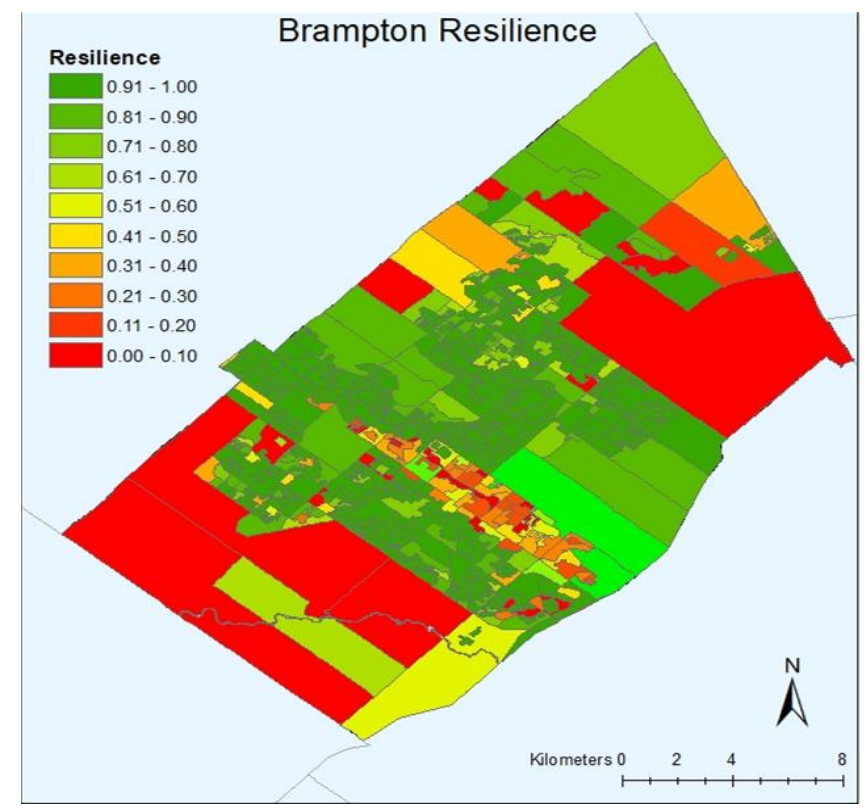

Figure 9. Integrated resilience map for the City of Brampton (normalized); higher resilience value indicates a higher level of resilience.

\section{Discussion and Conclusions}

The core objective of this study was to develop a methodology to capture community perceptions of flood hazard risk based on their exposure, susceptibility, and lack of coping capacity, and incorporate 
those perceptions into estimating community resilience. Inspired by the world risk index (WRI), we have successfully demonstrated that the WRI determinants can be used to explain the difference between how risk is perceived and the factual picture presented by the objective data. We estimate objective resilience using actual data related to exposure (dangerous locations), susceptibility (derived from demographic data), and lack of coping capacity (derived from a combination of census and landuse data). The two resilience measures, perceived and objective, were combined by adding them and normalizing the resulting combined resilience. It should be noted that the perceived and objective parameters were normalized at the unweighted stage that justifies the similar treatment of the two (perceived and objective). The study should be used as a decision-making tool to enhance the resilience of communities based on their circumstances.

We used a questionnaire to engage people, but it should be noted that some of the nuances of the methodology were under development at the time of the survey. The randomly selected respondents were residents of the City of Brampton, as reflected by their use of the community centre, sports centre, the church and the restaurant used as survey locations. We acknowledge the small sample size of 100 participants that may have led to a rather underwhelmingly visual difference in the perceived and objective resilience measures. The reason for that to happen could be the fact that a small sample from each survey site was used to represent an entire region determined by the Thiessen polygon method. Furthermore, with a limited representation of the community in the study area, the perceived data estimates are bound to have uncertainties that can be addressed with extensive survey data. The determination of the buffer zones for different exposure variables was made by treating the variables such as highways and rivers in a similar manner. However, this aspect needs to be improved by allowing different buffer zones for various variables.

In summary, this research makes a reasonable preliminary attempt toward achieving a better representative measure of the resilience of a community in the context of disasters and emergencies. Future research is recommended for examining current disaster mitigation policies in Ontario, engaging representative communities to capture their perceptions, and looking at how specific changes can be made in those policies to improve their relevance and outcome for a diverse population. Solutions to disaster risk reduction and preparedness strategies lie in meaningful consultation with stakeholders, no matter how insignificant some may seem. We recommend future research to refine the methodology along with its various aspects presented here. The approach should also be user-friendly for a broader application. In Canada, the most frequent hazard, flooding, and other disasters are managed by the local authorities first; the province assists if local capacities prove to be insufficient; and eventually, the federal government helps if the consequences are too severe. In many cases, the federal help arrives when it is too late due to unclear guidance, inconsistent messaging, political and ideological differences among actors, and conflicting priorities. There is a need, now more than ever before, to develop a national strategy for resilience to all disasters to enable an environment of swift impact assessment of events and allocation of resources across the nation.

Author Contributions: Conceptualization, methodology, and data curation by N.A.; data processing and analysis, M.E. and N.A.; visualization, M.E.; supervision, N.A. and S.P.S.; funding acquisition, S.P.S. and N.A. All authors have read and agreed to the published version of the manuscript.

Funding: Funding from NSERC-CREATE-ADERSIM and York University Minor Research Grant.

Acknowledgments: Funding from NSERC-CREATE-ADERSIM and York University Minor Research Grant made the study possible. It offered high-quality training opportunities for York University students, Mark Elliott from Environmental Studies for the GIS work, and Judith Jubril and Sarah-Maude Guindon from Master of Disaster and Emergency Management (MDEM) toward the surveys. Thanks to Alain Normand, Manager, Emergency Management, the City of Brampton, for helping with logistics in conducting community surveys. Sabrina Daddar, MDEM, also contributed in liaising with community partners in the initial stages.

Conflicts of Interest: The authors declare no conflict of interest. 


\section{Appendix A List of Data Sources}

\begin{tabular}{|c|c|}
\hline Data & Source \\
\hline \multicolumn{2}{|l|}{ Exposure } \\
\hline & DMTI Spatial, 2015 \\
\hline Highways & http://geo.scholarsportal.info/\#r/details/_uri@=2347499980 \\
\hline Rail Lines & Ontario Ministry of Natural Resources, 2012 \\
\hline Industrial Sites & $\begin{array}{l}\text { Canada, Federal Government Open Data Program, created by request, } \\
2016\end{array}$ \\
\hline GTA Pipes, Transmission Lines & DMTI Spatial, 2014 \\
\hline Slope and DEM & DMTI Spatial, 2015 (retired) \\
\hline Major Rivers & Provided by Toronto and Region Conservation Authority \\
\hline \multicolumn{2}{|l|}{ Susceptibility } \\
\hline Home Ownership & Statscan, 2011 census data via http://dc1.chass.utoronto.ca/census/ \\
\hline Age of Construction & Statscan, 2011 census data via http://dc1.chass.utoronto.ca/census/ \\
\hline Language Skills & Statscan, 2011 census data via http://dc1.chass.utoronto.ca/census/ \\
\hline Employment & Statscan, 2011 census data via http://dc1.chass.utoronto.ca/census/ \\
\hline Age & Statscan, 2011 census data via http://dc1.chass.utoronto.ca/census/ \\
\hline Disability & Statistics Canada, by request, 2017 \\
\hline Property Value & $\begin{array}{l}\text { online real estate listings (ReMax), geocoded by address in ArcGIS } \\
\text { Online }\end{array}$ \\
\hline \multicolumn{2}{|l|}{ Coping Capacity } \\
\hline GTA Fires Stations & http://geo.scholarsportal.info/\#r/details/_uri@=3739967620 \\
\hline GTA Police Stations & http://geo.scholarsportal.info/\#r/details/_uri@=3739967620 \\
\hline GTA Hospitals & http://geo.scholarsportal.info/\#r/details/_uri@=3570906326 \\
\hline Ambulance Stations & $\begin{array}{l}\text { Addresses gathered from publicly available information at municipal } \\
\text { websites, Wikipedia, and Google; geocoded using ArcGIS Online }\end{array}$ \\
\hline Income & Statscan, 2011 census data via http://dc1.chass.utoronto.ca/census/ \\
\hline Education & Statscan, 2011 census data via http://dc1.chass.utoronto.ca/census/ \\
\hline \multicolumn{2}{|l|}{ Miscellaneous } \\
\hline Watercourses & Ontario Ministry of Natural Resources, 2011 \\
\hline Watersheds & Ontario Ministry of Natural Resources, 2011 \\
\hline Dissemination Areas & $\begin{array}{l}\text { University of Toronto Census Analyzer } \\
\text { http://dc1.chass.utoronto.ca/census/ }\end{array}$ \\
\hline Land Use & $\begin{array}{l}\text { DMTI Spatial, } 2014 \text { http://geo.scholarsportal.info/\#r/details/_uri@ } \\
=2785150059 \$ \text { DMTI_2014_CanMapRL_Topo_LUR_ALL_PROV }\end{array}$ \\
\hline Census Tracts & $\begin{array}{l}\text { University of Toronto Census Analyzer http://dc1.chass.utoronto.ca/cgi- } \\
\text { bin/census/2011nhs/displayCensus.cgi?year=2011\&geo }=\mathrm{ct}\end{array}$ \\
\hline GTA Municipalities & $\begin{array}{l}\text { DMTI Spatial, } 2014 \text { http://geo.scholarsportal.info/\#r/details/_uri@ } \\
=4044335176 \$ D M T I 2014 \text { CanMapRL_Streets_MUN_ALL_PROV }\end{array}$ \\
\hline Education & $\begin{array}{l}\text { DMTI Spatial, } 2015 \\
\text { http://geo.scholarsportal.info/\#r/details/_uri@=4062179246 }\end{array}$ \\
\hline
\end{tabular}

\section{References}

1. Pazzi, V.; Morelli, S.; Pratesi, F.; Sodi, T.; Valori, L. Assessing the safety of schools affected by geo-hydrologic hazards: The geohazard safety classification (GSC). Int. J. Disaster Risk Reduct. 2016, 15, 80-93. [CrossRef]

2. Schiermeier, Q. Increased flood risk linked to global warming. Nature 2011, 470, 316. [CrossRef]

3. Bempah, S.A.; Oyhus, A.O. The role of social perception in disaster risk reduction: Beliefs, perception, and attitudes regarding flood disasters in communities along the Volta River, Ghana. Int. J. Disaster Risk Reduct. 2017, 23, 104-108. [CrossRef]

4. Ranjan, E.S.; Abenayake, C.C. A study on community's perception on disaster resilience concept. Procedia Econom. Financ. 2014, 18, 88-94. [CrossRef]

5. Cutter, S. Preface. In Disaster Resilience: A National Imperative, Committee on Increasing National Resilience to Hazards and Disasters; The National Academies Press: Washington, DC, USA, 2011; p. 244.

6. Cutter, S.L.; Barnes, L.; Berry, M.; Burton, C.; Evans, E.; Tate, E. A place-based model for understanding community resilience to natural disasters. Glob. Environ. Chang. 2008, 18, 598-606. [CrossRef] 
7. Birkholz, S.; Muro, M.; Jeffrey, P.; Smith, H.M. Rethinking the relationship between flood risk perception and flood management. Sci. Total Environ. 2014, 478, 12-20. [CrossRef] [PubMed]

8. Santoro, S.; Pluchinotta, I.; Pagano, A.; Pengal, P.; Cokan, B.; Giordano, R. Assessing stakeholders' risk perception to promote Nature Based Solutions as flood protection strategies: The case of the Glinščica River (Slovenia). Sci. Total Environ. 2019, 655, 188-201. [CrossRef] [PubMed]

9. Lei, Y.; Wang, J.; Yue, Y.; Zhou, H.; Yin, W. Rethinking the relationships of vulnerability, resilience, and adaptation from a disaster risk perspective. Nat. Hazards 2014, 70, 609-627. [CrossRef]

10. Hyogo Framework for Action (HFA) 2005-2015 Building the Resilience of Nations and Communities to Disasters. Available online: www.unisdr.org (accessed on 4 April 2020).

11. Sendai Framework for Disaster Risk Reduction (SF-DRR) 2015-2030; The United Nations Office for Disaster Risk Reduction: Geneva, Switzerland. Available online: www.unisdr.org (accessed on 4 April 2020).

12. Cutter, S.L.; Boruff, B.J.; Shirley, W.L. Social vulnerability to environmental hazards. Soc. Sci. Q. 2003, 84, 242-261. [CrossRef]

13. Few, R. Flooding, vulnerability and coping strategies: Local responses to a global threat. Prog. Dev. Stud. 2003, 3, 43-58. [CrossRef]

14. Messner, F.; Meyer, V. Flood damage, vulnerability and risk perception-Challenges for flood damage research. In Flood Risk Management: Hazards, Vulnerability and Mitigation Measures; NATO Science Series; Schanze, J., Zeman, E., Marsalek, J., Eds.; Springer: Dordrecht, The Netherlands, 2006; Volume 67.

15. Kuhlick, C.; Scolobig, A.; Tapsell, S.; Steinführer, A.; Marchi, B.D. Contextualizing Social Vulnerability: Findings from Case Studies across Europe; Springer Science \& Business Media B.V.: New York, NY, USA, 2011.

16. Burns, J.W.; Slovic, P. Risk perception and behaviors: Anticipating and responding to crises. Risk Anal. 2012, 32, 579-582. [CrossRef] [PubMed]

17. Paton, D.; Johnston, D. Disaster Resilience: An Integrated Approach, 2nd ed.; Charles, C., Ed.; Thomas Publisher: Springfield, IL, USA, 2017; p. 438.

18. Chang, S.E.; Shinozuka, M. Measuring improvements in the disaster resilience of communities. Earthq. Spectra 2004, 20, 739-755. [CrossRef]

19. Welle, T.; Birkmann, J. The World Risk Index-An approach to assess risk and vulnerability on a global scale. J. Extreme Events 2015, 2, 1550003. [CrossRef]

20. Folke, C.; Carpenter, S.R.; Walker, B.; Scheffer, M.; Chapin, T.; Rockström, J. Resilience thinking: Integrating resilience, adaptability and transformability. Ecol. Soc. 2010, 15, 20-29. [CrossRef]

21. Folke, C. Resilience: The emergency of a perspective for social-ecological systems analyses. Glob. Environ. Chang. 2006, 16, 253-267. [CrossRef]

22. Kuhlicke, C.; Steinführer, A. Preface: Building social capacities for natural hazards: An emerging field for research and practice in Europe. Nat. Hazards Earth Syst. Sci. 2015, 15, 2359-2367. [CrossRef]

23. McEwen, L.J.; Krause, F.; Jones, O.; Garde-Hansen, J. Sustainable flood memories, informal knowledge and the development of community resilience to future flood risk. WIT Trans. Ecol. Environ. 2012, 159, 253-264.

24. Ashley, R.M.; Blanskby, J.; Newman, R.; Gersonius, B.; Poole, A.; Lindley, G.; Smith, S.; Ogden, S.; Nowell, R. Learning and action alliances to build capacity for flood resilience. J. Flood Risk Manag. 2012, 5, 14-22. [CrossRef]

25. Schelfaut, K.; Pannemans, B.; van der Craats, I.; Krywkow, J.; Mysiak, J.; Cools, J. Bringing flood resilience into practice: The FREEMAN project. Environ. Sci. Policy 2011, 14, 825-833. [CrossRef]

26. Hung, H.C.; Yang, C.Y.; Chien, C.Y.; Liu, Y.C. Building resilience: Mainstream community participation into integrated assessment of resilience to climatic hazards in metropolitan land use management. Land Use Policy 2016, 50, 48-58. [CrossRef]

27. WMO. Building Resilience through Community Participation-A Report on the Pilot Project on Community Flood Management in Bangladesh, India and Nepal; WMO: Geneva, Switzerland, 2017.

28. UN-DRR. United Nations Office for Disaster Risk Reduction. Available online: https://www.undrr.org/ terminology/capacity (accessed on 4 April 2020).

29. Birkmann, J. (Ed.) Basic principles, and theoretical concepts. In Measuring Vulnerability to Natural Hazards: Towards Disaster Resilient Societies; United Nations University Press: Tokyo, Japan, 2006; p. 524.

30. Birkmann, J.; Cardona, O.D.; Carreno, M.L.; Barbat, A.H.; Pelling, M.; Scheiderbauer, S.; Kienberger, S.; Keiler, M.; Alexandar, D.; Zeil, P.; et al. Framing vulnerability, risk and societal responses: The MOVE framework. Nat. Hazards 2003, 67, 193-211. [CrossRef] 
31. Boin, A.; Comfort, L.K.; Demchak, C.C. The rise of resilience. In Designing Resilience: Preparing for Extreme Events; Comfort, L.K., Boin, A., Demchak, C.C., Eds.; University of Pittsburgh Press: Pittsburgh, PA, USA, 2010.

32. Britton, N.R.; Clark, G.J. From response to resilience: Emergency management reform in New Zealand. Nat. Hazards Rev. 2000, 1, 145-150. [CrossRef]

33. Brooks, N. Vulnerability, risk, and adaptation: A conceptual framework. Tyndall Cent. Clim. Chang. Res. Work. Pap. 2003, 38, 1-16.

34. Simonovic, S.P.; Peck, A. Dynamic resilience to climate change caused natural disasters in coastal megacities quantification framework. Br. J. Environ. Clim. Chang. 2013, 3, 378-401. [CrossRef]

35. Timmerman, P. Vulnerability, resilience and the collapse of society: A review of models and possible climatic applications. In Environmental Monograph No. 1; Institute for Environmental Studies, University of Toronto: Toronto, ON, Canada, 1981.

36. Turner, B.L. Vulnerability and resilience: Coalescing or paralleling approaches for sustainability science? Glob. Environ. Chang. 2010, 20, 570-576. [CrossRef]

37. Government of Canada. Emergency Management Strategy for Canada: Toward a Resilient 2030; Public Safety Canada Report; Public Safety Canada: Ottawa, ON, Canada, 2019; ISBN 978-0-660-29248-9.

38. EM-DAT. The International Disaster Database, Centre for Research on the Epidemiology of Disasters 2019. Available online: http://www.emdat.be/disaster_trends/index.html (accessed on 16 March 2020).

39. Canadian Disaster Database. Public Safety Canada 2019. Available online: https://www.publicsafety.gc.ca/ cnt/mrgnc-mngmnt/ntrl-hzrds/index-en.aspx (accessed on 16 March 2020).

40. Nirupama, N.; Maula, A. Engaging public for building resilient communities to reduce disaster impact. Nat. Hazards 2013, 66, 51-59. [CrossRef]

41. Nirupama, N.; Etkin, D. Institutional perception and support in emergency management in Ontario, Canada. Disaster Prev. Manag. 2012, 21, 599-607. [CrossRef]

42. Nirupama, N.; Etkin, D. Emergency managers in Ontario: An exploratory study of their perspective. J. Homel. Secur. Emer. Manag. 2009, 6. [CrossRef]

43. Nirupama, N. Risk, and vulnerability assessment-A comprehensive approach. Int. J. Disaster Resil. Built Environ. 2012, 3, 2. [CrossRef]

44. Bruneau, M.; Chang, S.E.; Eguchi, R.T.; Lee, G.C.; O’Rourke, T.D.; Reinhorn, A.M.; Shinozuka, M.; Tierney, K.; Wallace, W.A.; von Winterfeldt, D. A framework to quantitatively assess and enhance the seismic resilience of communities. Earthq. Spectra 2003, 19, 733-752. [CrossRef]

45. Building Resilient Communities. Fort McMurray Wildfire: Learning from Canada's Costliest Disaster; Institute for Catastrophic Loss Reduction: Zurich, Switzerland, 2019.

46. McGee, T.K. Public engagement in neighbourhood level wildfire mitigation and preparedness: Case studies from Canada, the US and Australia. J. Environ. Manag. 2011, 92, 2524-2532. [CrossRef]

47. Koksal, K.; McLennan, J.; Bearman, C. Living with bushfires on the urban-bush interface. Aust. J Emerg. Manag. 2020, 35, 21-28.

48. Miller, F.; Osbahr, H.; Boyd, E.; Thomalla, F.; Bharwani, S.; Ziervogel, G.; Walker, B.; Birkmann, J.; Vander Leeuw, S.; Rockstro“m, J.; et al. Resilience and vulnerability: Complementary or conflicting concepts? Ecol. Soc. 2010, 15, 11. [CrossRef]

49. Slovic, P. The Feeling of Risk: New Perspectives on Risk Perception; Routledge: London, UK, 2010; p. 425.

50. Bandecchi, A.E.; Pazzi, V.; Morelli, S.; Valori, L.; Casagli, N. Geo-hydrological and seismic risk awareness at school: Emergency preparedness and risk perception evaluation. Int. J. Disaster Risk Reduct. 2019, 40, 101-280. [CrossRef]

51. Arnstein, S.R. A ladder of citizen participation. J. Am. Inst. Plan. 1969, 35, 216-224. [CrossRef]

52. Few, R.; Brown, K.; Tompkins, E. Public participation and climate change adaptation: Avoiding the illusion of inclusion. Clim. Policy 2007, 7, 46-59. [CrossRef]

53. Cutter, S.L.; Burton, C.G.; Emrich, C.T. Disaster Resilience indicators for benchmarking baseline conditions. J. Homel. Secur. Emerg. Manag. 2010, 7, 51. [CrossRef]

54. Armenakis, C.; Nirupama, N. Estimating spatial disaster risk in urban environments. Geomat. Nat. Hazards Risk 2013, 4, 289-298. [CrossRef] 
55. Irwin, S.; Simonovic, S.P.; Nirupama, N. Introduction to ResilSIM: A Decision Support Tool for Estimating Disaster Resilience to Hydro-Meteorological Events; Water Resources Research Report No. 094; Facility for Intelligent Decision Support, Department of Civil and Environmental Engineering, Western University: London, ON, Canada, 2016; p. 66. ISBN (print) 978-0-7714-3115-9; (online) 978-0-7714-3116-6.

56. Kovacs, P.; Kunreuther, H. Managing Catastrophic Risk: Lessons from Canada 2001. Available online: http://www.iclr.org/images/Managing_Catastrophic_Risk.pdf (accessed on 4 April 2020).

57. Smith, K. (Ed.) Environmental Hazards: Assessing Risk and Reducing Disaster, 2nd ed.; Routledge: London, UK, 1996.

58. Holling, C.S. Resilience and stability of ecological systems. Annu. Rev. Ecol. Syst. 1973, 4, 1-23. [CrossRef]

59. Kasperson, J.X.; Kasperson, R.E. The Social Contours of Risk; Earthscan: London, UK, 2005.

60. Klein, R.J.T.; Nicholls, R.J.; Thomalla, F.T. Resilience to natural hazards: How useful is this concept? Environ. Hazards 2003, 5, 35-45. [CrossRef]

61. McLaughlin, P. Climate change, adaptation, and vulnerability: Reconceptualizing societal-environment interaction within a socially constructed adaptive landscape. Organ. Environ. 2011, 24, 269-291. [CrossRef]

62. Paton, G. Disaster resilience: Building capacity to co-exist with natural hazards and their consequences. In Disaster Resilience; Charles C. Thomas Publishers: Springfield, IL, USA, 2006; p. 321.

63. Walker, B.; Holling, C.S.; Carpenter, S.R.; Kinzig, A. Resilience, adaptability and transformability in social-ecological systems. Ecol. Soc. 2004, 9, 5. [CrossRef]

64. Wisner, B.; Blaikie, P.; Cannon, T.; Davis, I. At Risk: Natural Hazards, People's Vulnerability, and Disasters, 2nd ed.; Routledge: London, UK, 2004; p. 471.

65. Bazeley, P. Qualitative Data Analysis: Practical Strategies; Sage Publications: Thousand Oaks, CA, USA, 2013; p. 472.

66. Creswell, J.W.; Shope, R.; Plano Clark, V.L.; Green, D.O. How interpretive qualitative research extends mixed methods research. Res. Sch. 2006, 13,1-11.

67. Ratner, C. Subjectivity and objectivity in qualitative methodology. Forum Qual. Soc. Res. 2002, 3, 16.

68. Mamuji, A.; Rozdilsky, J.L. Canada's 2016 Fort McMurray Wildfire Evacuation: Experiences of the Muslim Community. Int. J. Emerg. Manag. 2019, 15, 125-146. [CrossRef]

69. Siegrist, M.; Gutscher, H. Natural hazards and motivation for mitigation behavior: People cannot predict the affect evoked by a severe flood. Risk Anal. 2008, 28, 771-778. [CrossRef]

70. Simonovic, S.; Nirupama, N. A spatial multi-objective decision making under uncertainty for water resources management. J. Hydroinf. 2005, 7, 117-133. [CrossRef]

71. Minguez, C.; Fermina, G.; Perez, R., II. Doctorate in Geography Workshop. In Proceedings of the XXV Congress of the Association of Spanish Geographers, Madrid, Spain, 25-27 October 2017.

72. Malik, S.; Awan, H.; Khan, N. Mapping vulnerability to climate change and its repercussions on human health in Pakistan. Glob. Health 2012, 8, 31-41. [CrossRef]

73. Twigg, J. Characteristics of a Disaster-Resilient Community: A Guidance Note; DFID Disaster Risk Reduction Interagency Coordination Group, Hazard Research Centre, Benfield UCL: London, UK, 2007; p. 39.

74. Wallace, T.; Watkins, D.; Park, H.; Singhve, A.; Williams, J. How One Houston Suburb Ended up in a Reservoir; New York Times: New York, NY, USA, 2018.

(C) 2020 by the authors. Licensee MDPI, Basel, Switzerland. This article is an open access article distributed under the terms and conditions of the Creative Commons Attribution (CC BY) license (http://creativecommons.org/licenses/by/4.0/). 